\title{
Analysis of pituitary adenoma expression patterns suggests a potential role for the NeuroD1 transcription factor in neuroendocrine tumor-targeting therapies
}

\author{
Lubov Borisovna Mitrofanova ${ }^{1}$, Olga Mikhailovna Vorobeva ${ }^{1}$ and Andrey Nikolaevich \\ Gorshkov ${ }^{1,2}$ \\ ${ }^{1}$ Almazov National Medical Research Center, St. Petersburg, Russia \\ ${ }^{2}$ Smorodintsev Research Institute of Influenza, St. Petersburg, Russia \\ Correspondence to: Lubov Borisovna Mitrofanova, email: lubamitr@yandex.ru \\ Keywords: pituitary adenoma; NeuroD 1 transcription factor; confocal laser scanning microscopy; electron immunocytochemistry \\ Received: July 19, 2018 \\ Accepted: December 10, 2018 \\ Published: January 08, 2019 \\ Copyright: Mitrofanova et al. This is an open-access article distributed under the terms of the Creative Commons Attribution \\ License 3.0 (CC BY 3.0), which permits unrestricted use, distribution, and reproduction in any medium, provided the original author \\ and source are credited.
}

\section{ABSTRACT}

NeuroD1's roles in the pathogenesis of pituitary adenomas and in the biology of the normal adult pituitary gland have been insufficiently researched. Much of the work investigating its expression patterns has yielded contradictory results. Objective: morphological study of NeuroD1 transcription factor expression in different types of pituitary adenomas and in normal adult human pituitary glands. Materials and methods: This study analyzed 48 pituitary adenomas and nine normal pituitary glands. In all cases, immunohistochemical study was performed with antibodies to NeuroD1, 6 hormones of adenohypophysis, Ki-67, and CK7. We used confocal laser scanning microscopy, electron microscopy and electron immunocytochemistry. Results: NeuroD1 expression was detected in all cases of plurihormonal adenomas, mammosomatotropinomas, corticotropinomas, prolactinomas, gonadotropinomas, null-cell pituitary adenomas, and in normal pituitary glands. The average numbers of NeuroD1 expressing cells in normal adenohypophysis specimens were significantly lower than in the adenomas overall $(p=0.006)$. NeuroD1 expression was confirmed by several methods (in prolactinomas, by double stain immunohistochemistry; in mammosomatotropinomas, by double stain immunohistochemistry, confocal laser scanning microscopy, and electron immunocytochemistry; and in somatotropinomas, by electron immunocytochemistry). Conclusion: Immunohistochemistry, confocal microscopy, and double label electron immunocytochemistry confirmed NeuroD1's key role in the pathogenesis of pituitary tumors, regardless of their hormonal state. Its expression level in pituitary adenomas is significantly higher than in the normal pituitary gland and has no reliable correlation with any studied hormones or Ki-67. These findings suggest that NeuroD1 should be investigated further as a potential molecular target in tumor-targeting therapies.

\section{INTRODUCTION}

Pituitary adenomas comprise $15-20 \%$ of all intracranial tumors. They have various clinical manifestations depending on proliferative and hormonal activity. World Health Organization (WHO) guidelines for 2017 specify the following pituitary adenoma types: somatotroph adenomas (densely granulated somatotroph adenoma, sparsely granulated somatotroph adenoma, mammosomatotroph adenoma, mixed somatotrophlactotroph adenoma); lactotroph adenomas (sparsely granulated lactotroph adenoma, densely granulated lactotroph adenoma, acidophil stem cell adenoma); thyrotroph adenoma; corticotroph adenomas (densely granulated corticotroph adenoma, sparsely granulated corticotroph adenoma, crooke's cell adenoma); gonadotroph 
adenoma; null cell adenoma; plurihormonal adenomas (Pit-1-positive plurihormonal adenoma, previously termed silent subtype 3 adenoma); and adenomas with unusual immunohistochemical combinations [1].

The impacts of pituitary tumors are diverse, and symptoms range from nonexistent to severe. Pituitary tumors that secrete hormones (functioning) can cause a variety of signs and symptoms depending on the hormones they produce. Tumors that do not secrete hormones (nonfunctioning) cause signs and symptoms as result of their growth and impingement on other structures. Signs and symptoms of pituitary tumor pressure may include vision loss, headaches, and loss of peripheral vision in particular. Hormone dysregulation induced symptoms can include: menstrual changes; sexual dysfunction; elevated blood sugar or pressure; body weight changes; adipose distribution changes (accumulation at the midsection and upper back); thinning of the extremities; diuresis; weakness; nausea; vomiting; feeling cold; weakening of bones; cardiac problems; exaggerated facial features; depression, anxiety, or irritability (adrenocorticotropic hormone-secreting tumors); acne; misaligned teeth; increased body hair (growth hormone-secreting tumors); excess sweating; enlarged hands and feet; stretch marks; propensity to bruising; joint pain; and other symptoms [2].

Therefore, despite their classification as benign, pituitary adenomas can be clinically serious, and they often represent a significant burden. The main treatment method for adenoma is transsphenoidal resection, but they often recur following intervention. Surgical remission rates of up to $60 \%$ have been reported [3, 4]. Our continually improving understanding of pituitary cell molecular biology has allowed effective, targeted therapies to be developed. If pharmacotherapy is needed after surgery, dopamine agonists are recommended for adenomas that dual secrete growth hormone (GH) and prolactin because both expression pathways are targeted by these agents. In GH-secreting adenomas, somatostatin receptors (SSTR2 and SSTR5 subtypes) make up $90-95 \%$ of receptor expression. Lanreotide and octreotide are the main somatostatin analogs currently in use and they activate the signaling pathway to inhibit hormone production in functional adenomas [5, 6]. Targeted molecular therapy for acromegaly, using GH-receptor antagonists, represents a third example of success in terms of insights from molecular biology being translated into practice. The only GH-receptor antagonist approved by the FDA (United States Food and Drug Administration) available for the treatment of acromegaly is Pegvisomant. As a pegylated analog of human $\mathrm{GH}$, it competes directly with plasma GH for receptor binding [7]. Despite progress with somatotropinoma, the search for targeted therapies which are effective with other pituitary adenoma types continues.

In recent years, our understanding of the cellular and molecular biology of pituitary gland tumors has changed significantly. It is known that transcription factors (TFs) regulate the differentiation of pituitary precursor cells into mature secretory cells during embryogenesis $[8,9]$; those studies were performed mostly in animals. The relevant transcription factors are thought to be Prop-1, Pit-1, Pitx1, NeuroD1, SF1, Gata2, RPx/Hes1, Pitx1, Ptx2, Lhx3/ LIM3/P-Lim, and others. It is known that the NeuroD1 TF participates in corticotroph formation. Corticotrophs are the first cells which differentiate in the developing pituitary gland [10]. In the NeuroD family, three isoforms have been identified: NeuroD1, NeuroD2, and NeuroD3. NeuroD1 and NeuroD2 are initially produced during embryogenesis and remain in the adult nervous system unlike NeuroD3, which is only briefly expressed in the 9-10th week of gestation. NeuroD family proteins are also expressed in primitive neuroectodermal tumors. NeuroD1 was found in pancreatic endocrine cells and was named BETA2 (b-cell trans-activator E-box 2). Mice with NeuroD1 mutations die soon after birth from severe neonatal diabetes. Its synergism with a different transcription factor, Pitx1, has also been described [11]. NeuroD1's role in the pathogenesis of pituitary adenomas and in the biology of the normal adult pituitary gland has been insufficiently researched. Much of the work addressing its expression is contradictory. For example, it is understood that Neuro D1 participates in the formation of corticotrophs and is expressed in corticotropinomas, yet it has been seen in thyrotropinomas and null-cell pituitary adenomas. Collectively, these various patterns show that more work is needed to fully understand Neuro D1 [12].

NeuroD1 is known to play an important role in neuronal differentiation [13, 14]. Because of its importance during embryonic neurogenesis, it has been recently used in work aiming to reprogram other somatic cell types into becoming neurons. One study used a combination of factors (Pou3f2, Ascl1, Myt11, NeuroD1) to successfully reprogram fetal and postnatal fibroblasts into neurons [15]. In addition, NeuroD1 alone was capable of converting reactive glial cells into functional neurons in vivo; it was also able to convert human astrocytes into glutamatergic neurons [16]. Some researchers (Pataskar et al.) have concluded that NeuroD1 is a powerful factor involved in neuron development [17]. In light of NeuroD1's range of functions, and contradictory data on its expression in pituitary adenomas, it seems plausible to us that its role may not be limited to simply support of corticotroph formation.

Objective: morphological study of NeuroD1 transcription factor expression in different types of pituitary adenomas and in normal adult human pituitary glands.

\section{RESULTS}

\section{Plurihormonal pituitary adenomas}

This group included clinically diagnosed somatotropinomas (two cases), corticotropinomas (two cases), prolactinoma (one case), and non-functioning 
pituitary adenomas (two cases). According to magnetic resonance imaging data, the average size of plurihormonal adenomas was $14 \times 14 \times 12 \mathrm{~mm}$. The microscopic morphologies of plurihormonal pituitary adenomas were the most heterogeneous of all adenoma types. Solid, trabecular, papillary, and sinusoidal structures were seen in the tumors, sometimes in combination (Figure 1). They were PAS stain negative. In the plurihormonal adenomas, hormone expression (when present) was cytoplasmic, and NeuroD1 expression was nuclear. NeuroD1 expression was seen in all cases.

The average numbers of cells expressing given markers were: ACTH $21.2 \pm 24.8 \%$ (from $5 \%$ to $76 \%$ ); Prolactin $20.6 \pm 12.3 \%$ (from $3.8 \%$ to $45.1 \%$ ); GH $4.2 \pm 3.6 \%$ (from $1.3 \%$ to $10 \%$ ); FSH $0.2 \pm 0.3 \%$ (from $0 \%$ to $0.9 \%$ ); LH $1.9 \pm 2.7 \%$ (from $0 \%$ to $7.2 \%$ ); TSH $0.8 \pm 1.8 \%$ (from $0 \%$ to $5 \%$; Figure 2); and NeuroD1 $89.4 \pm 13.4 \%$ (from $69.9 \%$ to $99.5 \%$; Figure 3, Table 1). The Ki-67 index was $1.4 \pm 1.2 \%$ (from $0.1 \%$ to $3.3 \%$ ). Double stain immunohistochemistry revealed co-expression patterns. PRL and NeuroD1 were co-expressed in $5.2 \%$ of cells, on average (from 1.1 to $31.1 \%$ ). GH and NeuroD1 were co-expressed in $4.6 \%$ of cells, on average (from 2.9 to $8.4 \%$ ) (Figure 4A, B).

\section{Corticotropinomas}

This group contained seven cases of clinically diagnosed corticotropinoma and one case of prolactinoma. According to magnetic resonance imaging data, the average size of corticotropinomas was $25 \times 23 \times 23 \mathrm{~mm}$. Densely granulated corticotropinoma was diagnosed in five cases, and sparsely granulated corticotropinoma was diagnosed in three cases. Secretory granules of densely granulated corticotropinomas were strongly PAS-positive and immunohistochemistry revealed CK7 expression in the cytoplasm of these tumors.

In the corticotropinoma group, the average number cells expressing ACTH was $51.1 \pm 17.4 \%$ (from $21 \%$ to $78 \%$ ), and the average number cells expressing prolactin was $0.7 \pm 0.7 \%$ (from $0.1 \%$ to $1.8 \%$ ). Expression of other hormones was not seen. NeuroD1 TF signal was seen in all cases. The average number of NeuroD1 expressing cells was $94.9 \pm 4.1 \%$ (from $87.8 \%$ to $99.7 \%$ ), and the $\mathrm{Ki}-67$ index was $0.8 \pm 0.6 \%$ (from $0.1 \%$ to $1.7 \%$ ). When comparing the average numbers of NeuroD1 expressing cells in all adenoma types by immunohistochemistry, statistically significant differences were seen between corticotropinomas and gonadotropinomas $(p=0.02)$.

\section{Mammosomatotropinomas}

In this group, there were eight cases of clinically diagnosed somatotropinoma and two cases of prolactinoma. According to magnetic resonance imaging data, the average size of mammosomatotropinomas was $22 \times 16 \times 19$ $\mathrm{mm}$. Histological study revealed adenomas with diffuse or sinusoidal structure, consisting of cells with rounded, relatively monomorphic nuclei and distinguished nucleoli.



Figure 1: Plurihormonal pituitary adenoma with trabecular structure, hematoxylin and eosin, $\times 100$. 
Samples generally showed acidophilic cytoplasm and focal chromophobe cells. All 10 adenomas expressed CK7.

In mammosomatotropinomas, the average numbers of cells expressing given markers were: prolactin $50.0 \pm 10.3 \%$ (33.0-61.2\%); GH 30.2 $\pm 8.8 \%$ (18.5-41.1\%; Figure 5); and NeuroD1 $97.4 \pm 2.6 \%(92.9-99.7 \%)$. The Ki-67 index was $1 \pm 0.5 \%(0.3-1.9 \%)$. NeuroD1 signal was seen in all samples. Double stain immunohistochemistry revealed PRL and NeuroD1 co-expression in $8 \%$ of cells, on average (from 6.5 to $9.3 \%$ ). $\mathrm{GH}$ and NeuroD1 were co-expressed in $99.6 \%$ of cells, on average (from 97.6 to $99.8 \%$ ) (Figure 6).

According to confocal laser scanning microscopy (CLSM) data, the average NeuroD1 expression coefficient was $75 \%$. In the three mammosomatotropinoma samples (studied by CLSM) the coefficients of prolactin/NeuroD1 co-expression were: $30 \% ; 16 \%$; and $18 \%(21.3 \pm 6.1 \%$ average). The GH/NeuroD1 co-expression coefficients were: $77 \%$; $86 \%$; and $90 \%$ (84.3 $\pm 5.4 \%$ average). Figure 7 and Supplementary Figure 1 present dual label imaging data regarding the coexpression pairs mentioned above. The intensity of expression (fluorescence) of NeuroD1 was 145 1794 standard units, compared to 36-2135 standard units for DAPI (Figure 7F, 7L and Supplementary Figure 1F, 1L).

Electron immunocytochemistry was used to reveal the ultrastructural organization of the mammosomatotropinoma cells and to investigate NeuroD1's localization therein. It was found that mammosomatotropinoma cell shapes were nearly round, or slightly polygonal, with rounded nuclei, and sometimes having small invaginations (Figure 8A). Cytoplasma were filled with a large number of secretory granules; they varied significantly by size and electron density. Granule diameters ranged from 150 to $600 \mathrm{~nm}$. While large granules had high electron densities, their smaller counterparts ranged from relatively electrontransparent to electron-dense.

The distribution of granules in tumor cells varied. We identified cells featuring mainly large (500-600 nm) electron-dense granules (Figure 8B, lower section) and also cells with equally dispersed large and smaller granules (150-400 nm) (Figure 8B, upper section; Figure 8C). Along with secretory granules, specific features seen in mammosomatotropinoma cells included developed rough endoplasmic reticulum (Figure 8C) and an abundance of tonofilaments. In some cases, tonofilaments formed small, rounded inclusions in the perinuclear cytoplasm (Figure 8B), but more often they were organized in separate bundles (Figure $8 \mathrm{C}$ ). Indirect immunodetection of NeuroD1 by the immunogold method revealed multiple colloidal gold labeling of mammosomatotropinoma cell nuclei; neuroD1 concentration was observed in 200-300 $\mathrm{nm}$ electron-dense nuclear structures (Figure 9).

\section{Prolactinomas}

This group included six cases of clinically diagnosed prolactinoma and two cases of nonfunctioning pituitary adenoma. According to magnetic resonance imaging data, the average prolactinoma size was $25 \times 25 \times 24 \mathrm{~mm}$. In this group, densely granulated adenomas were rarely seen. All of the adenomas were chromophobic; they featured solid structure and perivascular pseudorosette formations.

In prolactinomas, the average numbers of cells expressing given markers were: prolactin $45.8 \pm 5.6 \%$ (from $40 \%$ to $55 \%$ ); ACTH $0.05 \pm 0.08 \%(0-0.2 \%$ ); $\mathrm{GH}$ $0.03 \pm 0.04 \% \quad(0.04-0.1 \%) ;$ and NeuroD1 $98.9 \pm 0.6 \%$ (98.2-99.3\%). The Ki-67 index was $3 \pm 2 \%(0.8-4.6 \%)$. NeuroD1 was expressed in the nuclei in all prolactinoma cases. Double stain immunohistochemistry revealed PRL



Figure 2: Average hormone expression values in plurihormonal pituitary adenomas. Numbers indicate the average number of hormone expressing cells (percent). 
NeuroD1 co-expression in $99.2 \%$ of cells, on average (from 88.0 to $100.0 \%$; Figure 10 ).

\section{Somatotropinomas}

Clinically, somatotropinomas manifested as acromegalia and chiasmal syndrome. The two adenomas were $24 \times 23 \times 22 \mathrm{~mm}$ and $28 \times 27 \times 26 \mathrm{~mm}$ in size. Histologically, adenoma structure was chromophobe, solid, and with perivascular pseudorosette formations.

In the two specimens, the average numbers of cells expressing markers were: 53.2 and $71.5 \%$ for $\mathrm{GH}$;
98.4 and $99.2 \%(92.9-99.7 \%)$ for NeuroD1. The Ki67 indices were 0.3 and $1.2 \%$. In both cases, electron immunocytochemistry revealed co-expression of NeuroD1 and $\mathrm{GH}$ in the same cell. Gold label $10 \mathrm{~nm}$ in diameter, indicating NeuroD1 detection, was observed in nuclei. Gold label $5 \mathrm{~nm}$ in diameter, indicating GH detection, was observed in cytoplasmic secretory granules (Figure 11).

\section{Gonadotropinomas}

All 5 gonadotropinomas clinically manifested as non-functioning pituitary adenomas. Patient symptoms


Figure 3: Immunohistochemistry, NeuroD1 in different pituitary adenomas. Expression of Neuro D1 seen as brown staining of tumor cell nuclei; x200. (A) Plurihormonal adenoma. (B) Mammosomatotropinoma. (C) Prolactinoma. (D) Gonadotropinoma. (E) Nullcell adenoma. (F) Somatotropinoma. 
Table 1: Average hormone and NeuroD1 expression values

\begin{tabular}{|c|c|c|c|c|c|c|c|}
\hline \multirow[t]{2}{*}{ Sample } & \multicolumn{7}{|c|}{ Average hormone and NeuroD1 expression values (in percent) } \\
\hline & $\begin{array}{c}\text { ACTH } \\
\text { average } \\
\text { min-max }\end{array}$ & $\begin{array}{c}\text { PRL } \\
\text { average } \\
\text { min-max }\end{array}$ & $\begin{array}{c}\text { GH } \\
\text { average } \\
\text { min-max }\end{array}$ & $\begin{array}{c}\text { FSH } \\
\text { average } \\
\text { min-max }\end{array}$ & $\begin{array}{c}\text { LH } \\
\text { average } \\
\text { min-max }\end{array}$ & $\begin{array}{c}\text { TSH } \\
\text { average } \\
\text { min-max }\end{array}$ & $\begin{array}{c}\text { NeuroD1 } \\
\text { average } \\
\text { min-max }\end{array}$ \\
\hline $\begin{array}{l}\text { Plurihormonal adenomas } \\
(\mathrm{n}=7)\end{array}$ & $\begin{array}{l}21.2 \pm 24.8 \\
5-76\end{array}$ & $\begin{array}{c}20.6 \pm 12.3 \\
3.8-45.1\end{array}$ & $\begin{array}{c}4.2 \pm 3.6 \\
1.3-10\end{array}$ & $\begin{array}{c}0.2 \pm 0.3 \\
0-0.9\end{array}$ & $\begin{array}{c}1.9 \pm 2.7 \\
0-7.2\end{array}$ & $\begin{array}{c}0.8 \pm 1.8 \\
0-5\end{array}$ & $\begin{array}{l}89.4 \pm 13.4 \\
69.9-99.5\end{array}$ \\
\hline $\begin{array}{l}\text { Null-cell adenomas } \\
(\mathrm{n}=8)\end{array}$ & 0 & 0 & 0 & 0 & 0 & 0 & $\begin{array}{l}94.1 \pm 5.8 \\
85.1-98.8\end{array}$ \\
\hline $\begin{array}{l}\text { Corticotropinomas } \\
(\mathrm{n}=8)\end{array}$ & $\begin{array}{l}51.1 \pm 17.4 \\
21-78\end{array}$ & $\begin{array}{l}0.7 \pm 0.7 \\
0.1-1.8\end{array}$ & 0 & 0 & 0 & 0 & $\begin{array}{c}94.9 \pm 4.1 \\
87.8-99.7^{*}\end{array}$ \\
\hline $\begin{array}{l}\text { Prolactinomas } \\
(\mathrm{n}=8)\end{array}$ & $\begin{array}{c}0.05 \pm 0.08 \\
0-0.2\end{array}$ & $\begin{array}{c}45.8 \pm 5.6 \\
40-55\end{array}$ & $\begin{array}{c}0.03 \pm 0.04 \\
0.04-0.1\end{array}$ & 0 & 0 & 0 & $\begin{array}{l}98.9 \pm 0.6 \\
98.2-99.3\end{array}$ \\
\hline $\begin{array}{l}\text { Mammosomatotropinomas } \\
(\mathrm{n}=10)\end{array}$ & 0 & $\begin{array}{l}50.0 \pm 10.3 \\
33.0-61.2\end{array}$ & $\begin{array}{l}30.2 \pm 8.8 \\
18.5-41.1\end{array}$ & 0 & 0 & 0 & $\begin{array}{c}97.4 \pm 2.6 \\
92.9-99.7\end{array}$ \\
\hline $\begin{array}{l}\text { Gonadotropinomas } \\
(\mathrm{n}=5)\end{array}$ & 0 & 0 & 0 & $\begin{array}{l}12.8 \pm 14.4 \\
0.2-35.3\end{array}$ & $\begin{array}{c}24.0 \pm 14.5 \\
10.5-45.8\end{array}$ & 0 & $\begin{array}{c}99.2 \pm 0.4 \\
98.8-99.8^{*}\end{array}$ \\
\hline $\begin{array}{l}\text { Normal pituitary } \\
(\mathrm{n}=9)\end{array}$ & $\begin{array}{l}44.7 \pm 10.0 \\
34.7-54.6\end{array}$ & $\begin{array}{l}52.2 \pm 4.6 \\
47.6-56.8\end{array}$ & $\begin{array}{l}46.3 \pm 13.1 \\
33.2-59.4\end{array}$ & $\begin{array}{l}52.3 \pm 7.5 \\
44.8-59.7\end{array}$ & $\begin{array}{r}18.7 \pm 3.6 \\
15.1-22.2\end{array}$ & $\begin{array}{l}31.1 \pm 8.6 \\
22.5-39.6\end{array}$ & $\begin{array}{c}67.8 \pm 23.3 \\
14-90^{*}\end{array}$ \\
\hline
\end{tabular}

* statistically significant differences in NeuroD1 levels between normal pituitary and adenomas.

in this group were dependent on tumor size. All patients experienced regular headaches, chronic weakness, and tunneling of vision; three of them had olfactory impairment. According to magnetic resonance imaging data, the average gonadotropinoma size was $23 \times 25 \times 27$ $\mathrm{mm}$. Gonadotropinomas consisted of elongated cells with monomorphous rounded nuclei, mostly occupying one pole of chromophobic cytoplasm. The tumors had sinusoidal or trabecular structures with focal perivascular pseudorosette formations.

In gonadotropinomas, the average numbers of cells expressing given markers were: LH $24.0 \pm 14.5 \%$ (10.5$45.8 \%)$; FSH $12.8 \pm 14.4 \%(0.2-35.3 \%)$; and NeuroD1 $99.2 \pm 0.4 \%$ (98.8-99.8\%). The Ki-67 index was $1.1 \pm 1 \%$ (0.3-2.9\%), and NeuroD1 TF signal was seen in all samples. Statistically significant differences in the average number of NeuroD1 expressing cells were registered between gonadotropinomas and null-cell adenomas $(p=0.004)$.

\section{Null-cell adenomas}

In this group, non-functioning pituitary adenoma was clinically diagnosed in all of the cases. The clinical presentations of the null-cell adenomas were primarily defined by the size of the tumor. According to magnetic resonance imaging data, the average size of null-cell pituitary adenomas was the largest one among the groups studied and equaled $33 \times 31 \times 31 \mathrm{~mm}$. The six cases with defined adenoma dimensions (according to MRI) comprised 3 macroadenomas (measuring more than $1 \mathrm{~cm}$ in one dimension) and 3 giant adenomas (measuring more than $4 \mathrm{~cm}$ in one dimension). Histologically, the null-cell adenomas consisted of monomorphous small rounded cells, with acidophilic or chromophobic cytoplasm, forming perivascular pseudorosettes. These tumors had solid or sinusoidal structures. Mitotic cells were not observed in the null-cell adenomas.

Hormone expression was not seen in the null-cell adenomas. Signal corresponding to NeuroD1 expression was seen in all of the cases. The average numbers of cells expressing NeuroD1was $94.1 \pm 5.8 \%$ (85.1-98.8\%). The Ki-67 index was $1.8 \pm 1.4(0.8-3.8 \%)$. Thus, the NeuroD1 $\mathrm{TF}$ was expressed, on average, in $95.5 \%$ of cells in all of the investigated adenoma types.

\section{Normal adenohypophysis tissue near adenoma boundaries}

Normal adenohypophysis areas expressing the majority of hormones, and consisting of expanded adenomeres, were found in 4 adenomas ( 3 plurihormonal and 1 gonadotropinoma) near tumor boundaries (Table 2). In these fragments, the average numbers of cells expressing given markers were: ACTH $61.8 \pm 7.6 \%$ (55.3-72.3\%); prolactin $46.9 \pm 2.5 \%$ (44.6-49.6\%); $\mathrm{GH}$ $28.7 \pm 12.0 \%$ (15.8-39.5\%); LG $31.8 \pm 19.9 \%$ (4.2-50.8\%); FSH $24.1 \pm 19.3 \%(3.1-49.1 \%)$; TSH $10.8 \pm 21.3 \%(0.2-$ $42.8 \%$ ); and NeuroD1 96.1 $1.0 \%$ (95.2-97.1\%).

When the average numbers of NeuroD1 expressing cells were compared in all of the sample groups, 
including normal adenohypophysis fragments near adenoma boundaries, significant differences were seen between gonadotropinomas and normal adenohypophysis (boundary) fragments $(p=0.02)$. Significant differences between the average number of NeuroD1 expressing cells in normal adenohypophysis fragments near adenoma boundaries and in normal pituitary gland were not seen $(p=0.8)$. This fact can be explained by the small number of cases (4).



\section{Normal adenohypophysis}

The pituitary glands investigated were from 9 to $13 \mathrm{~mm}$ long, from 6 to $10 \mathrm{~mm}$ wide, and from 5 to $8 \mathrm{~mm}$ high. Histological analysis included their anterior, intermediate, and posterior lobes. No signs of autolysis, dystrophy, or necrosis of cells were found in any pituitary glands. In the specimens, adenohypophysis comprised 70$75 \%$ of the total pituitary gland and consisted of many

Figure 4: (A) Double stain immunohistochemistry, plurihormonal adenoma, Prolactin/NeuroD1, $\times 200$. Prolactin is visualized with red colour, NeuroD1 with blue colour. Same cell co-expression of Prolactin and NeuroD1 is $11 \%$. Generally, the average number of cells with co-expression (Prolactin/NeuroD1) in this pituitary adenoma is $11.3 \pm 7.2 \%$. (B) Double stain immunohistochemistry, plurihormonal adenoma, Growth hormone/NeuroD1, $\times 200$. Growth hormone is visualized with red colour, NeuroD1 with blue colour. Same cell coexpression of Growth hormone/NeuroD1 is $12 \%$. Generally, the average number of cells with co-expression (Growth hormone/NeuroD1) in this pituitary adenoma is $10.0 \pm 3.1 \%$.



Figure 5: Average hormone expression values in mammosomatotropinomas. Numbers indicate the average number of hormone expressing cells (percent). 
glandular epithelial cells arranged in cords and clusters which were covered with reticular fibres and capillaries of trabeculae or adenomeres. The trabecular structures of anterior pituitaries were well defined using the Gordon and Sweet staining method for reticular fibres. The histological structures of pituitary glands from patients with cardiovascular diseases and/or chronic heart failure did not differ from those of patients with leukemia or uterine cancer; patients' cardiovascular status/disease did not have noticeable impacts on the pituitary.

In normal adenohypophysis, the average numbers of cells expressing given markers were: ACTH $44.4 \pm 6.6 \%$ (34.7-54.6\%); prolactin $52.0 \pm 3.1 \%(47.6-56.8 \%) ; \mathrm{GH}$ $46.8 \pm 8.3 \%$ (33.2-59.4\%); LG $18.8 \pm 2.5 \%$ (15.1-22.2\%); FSH $51.0 \pm 5.0 \%$ (44.8-59.7\%); TSH $29.8 \pm 5.5 \%$ (22.5$39.6 \%$ ); and NeuroD1 $67.7 \pm 24.8 \%$ (14.0-90.2\%). There were no statistically significant differences between patients in terms of any of the hormones (above).

Table 3 shows that in all of the normal specimens, all of the hormones are expressed in the tissue samples. It is worth mentioning that, unlike adenomas, the average number of NeuroD1 expressing cells in normal anterior pituitary was extremely variable (from 14 to $90.22 \%$; Figure 12). The lowest average number of NeuroD1 expressing cells was in a patient with uterine cancer (case number 8 in Table 3). The expression of hormones in this adenohypophysis specimen did not differ from that in patients with cardiovascular pathology. In a patient with leukemia, the average number of NeuroD1 expressing cells was much higher (case number 6, Table 3). Double stain immunohistochemistry revealed PRL and NeuroD1 co-expression in $50 \%$ of cells, on average (from 41 to $58 \%$ ). Co-expression of GH and NeuroD1 was seen in $45 \%$ of cells, on average (from 35 to $58 \%$; Figure 13).

The average numbers of NeuroD1 expressing cells in normal adenohypophysis specimens were significantly lower than in the adenomas overall ( $p=0.006$; Figure 14). In addition, significant differences were seen between the average number of pituicytes expressing NeuroD1 in normal anterior pituitary and in gonadotropinomas $(p=0.037)$ mammosomatotropinomas $(p=0.019)$, corticotropinomas $(p=0.019)$, or null-cell adenomas $(p=0.019)$. Correlation analysis did not show any significant relationships between the expression levels of NeuroD1, hormones, or Ki-67 in the pituitary gland $(p>0.05$; Figure 15$)$. There were no statistically significant differences between different types of adenomas in terms of mean Ki-67 values (Figure 16).

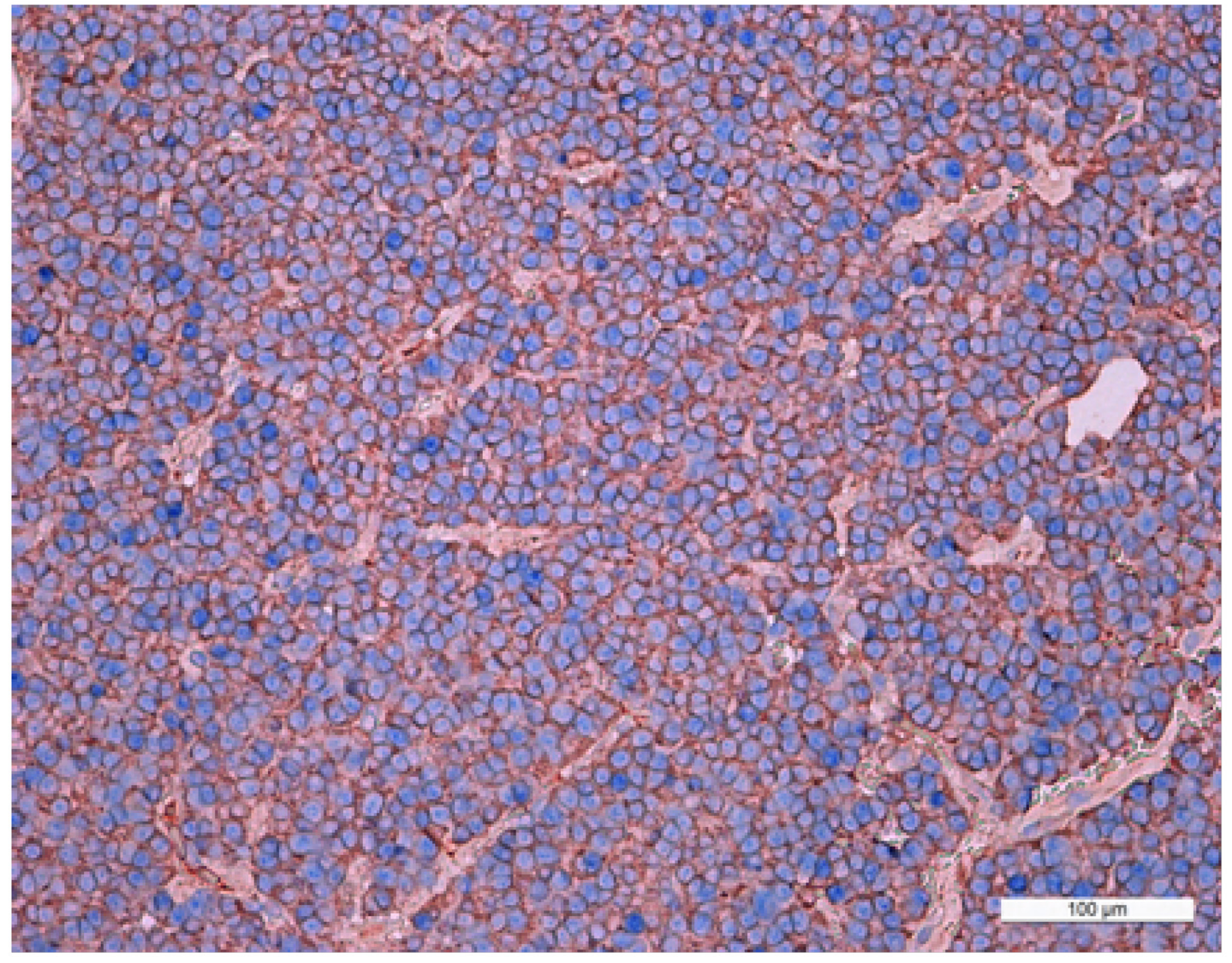

Figure 6: Double stain immunohistochemistry, mammosomatotropinoma, Growth hormone hormone/NeuroD1, $\times 200$. Growth hormone is visualized with red colour, NeuroD1 with blue colour. Same cell co-expression of Growth hormone and NeuroD1 is $100 \%$. Generaliiy, the average number of cells with co-expression (Growth hormone/NeuroD1) in this pituitary adenoma is $99.8 \%$. 



Figure 7: Confocal laser scanning microscopy, mammosomatotropinoma №1. (A): blue fluorescence of cell nuclei (DAPI); (B): green fluorescence of Prolactin; (C): red fluorescence of NeuroD1; (D): overlay image (A, B, C). NeuroD1(pink fluorescence)/Prolactin (green fluorescence) same cell co-expression is seen in $30 \%$ of the cells (indicated by arrows); $\times 600$; (E): scatterplot of blue (DAPI, Ch1) and red (Neuro D1, Ch 3) pixel intensities of tumor cell nuclei; (F): intensity histogram of red (Neuro D1), green (Prolactin), and blue (DAPI) fluorescence. White channel: light microscopy; (Continued) 



Figure 7 (Continued): Confocal laser scanning microscopy, mammosomatotropinoma №1. (G): blue fluorescence of cell nuclei (DAPI); (H): green fluorescence of Growth hormone; (I): red fluorescence of NeuroD1; (J): overlay image (G, H, I). NeuroD1 (pink fluorescence)/ Growth hormone (green fluorescence) same cell co-expression is seen in 77\% of the cells (indicated by arrows); $\times 2400$; (K): scatterplot of blue (DAPI, Ch1) and red (Neuro D1, Ch 3) pixel intensities of tumor cell nuclei; (L): intensity histogram of red (Neuro D1), green (Growth hormone), and blue (DAPI) fluorescence. White channel: light microscopy. 



Figure 8: Ultrastructure of mammosomatotropinoma cells. (A): general view of mammosomatotropinoma cells; (B and C): various types of secretory granules in the cytoplasm of mammosomatotropinoma cells. Abbreviations: $n$ : nuclei; sg: secretory granules; tf: tonofilaments; rer: rough endoplasmic reticulum. 




Figure 9: Immunogold labeling of Neuro D1, mammosomatotropinoma cell nucleus. Diffuse labeling in the nucleus is seen (arrows), with concentration of the label in 200-300 nm electron-dense nuclear structures (asterisks). Abbreviations: n: nucleus; ne: nuclear envelope; sg: secretory granules.



Figure 10: Double stain immunohistochemistry, prolactinoma, Prolactin/NeuroD1, $\times 200$. Prolactin is visualized with red colour, NeuroD1 with blue colour. PRL/NeuroD1 co-expression is seen in $90 \%$ of cells. 



Figure 11: Double immunogold labeling of NeuroD1 and GH, somatotropinoma cell. (A): micrograph of part of a single cell with selected areas of its nucleus and cytoplasm containing secretory granules shown in panels $b$ and $c$, respectively; (B): the nucleus of the cell is positive for Neuro D1 (10 nm gold particles, arrows); (C): secretory granules in the same cell are positive for GH $(5 \mathrm{~nm}$ gold particles, arrowheads). Abbreviations: n: nucleus; ne: nuclear envelope; sg: secretory granules. 
Table 2: Percentage of antigen expressing cells in normal adenohypophysis fragments taken near adenoma boundaries

\begin{tabular}{|c|c|c|c|c|c|}
\hline \multirow[t]{3}{*}{ Antibody } & \multicolumn{5}{|c|}{ Average number of antigen expressing cells } \\
\hline & \multicolumn{4}{|c|}{ Case number } & \multirow[t]{2}{*}{ Group average } \\
\hline & 1 & 2 & 3 & 4 & \\
\hline ACTH & $62.6 \%$ & $56.9 \%$ & $72.3 \%$ & $55.3 \%$ & $61.8 \pm 7.6 \%$ \\
\hline $\mathrm{GH}$ & $15.8 \%$ & $30.8 \%$ & $39.5 \%$ & - & $28.7 \pm 12.0 \%$ \\
\hline PRL & $44.6 \%$ & $46.6 \%$ & $49.6 \%$ & - & $46.9 \pm 2.5 \%$ \\
\hline LG & $50.8 \%$ & $32.3 \%$ & $39.9 \%$ & $4.2 \%$ & $31.8 \pm 19.9 \%$ \\
\hline FSH & $17.1 \%$ & $26.9 \%$ & $49.1 \%$ & $3.1 \%$ & $24.1 \pm 19.3 \%$ \\
\hline TSH & $0 \%$ & $0.2 \%$ & $0 \%$ & $42.8 \%$ & $10.8 \pm 21.3 \%$ \\
\hline NeuroD1 & $95.2 \%$ & $95.2 \%$ & $96.8 \%$ & $97.1 \%$ & $96.1 \pm 1.0 \%$ \\
\hline
\end{tabular}

«-» insufficient material for sectioning.

Table 3: Percentage of antigen expressing cells in normal adenohypophysis

\begin{tabular}{|c|c|c|c|c|c|c|c|c|c|c|}
\hline \multirow[t]{3}{*}{ Antibody } & \multicolumn{10}{|c|}{ Average number of antigen expressing cells } \\
\hline & \multicolumn{9}{|c|}{ Case number } & \multirow[t]{2}{*}{ Group Average } \\
\hline & 1 & 2 & 3 & 4 & 5 & 6 & 7 & 8 & 9 & \\
\hline ACTH & 39.5 & 52.3 & 34.7 & 41.9 & 42.4 & 54.6 & 38.7 & 48.8 & 46.9 & $44.4 \pm 6.6 \%$ \\
\hline $\mathrm{GH}$ & 33.2 & 53.7 & 36.9 & 49.1 & 42.4 & 45.2 & 59.4 & 49.7 & 51.4 & $46.8 \pm 8.3 \%$ \\
\hline PRL & 49.3 & 47.6 & 53.8 & 52.9 & 56.8 & 48.3 & 52.7 & 55.2 & 51.5 & $52.0 \pm 3.1 \%$ \\
\hline $\mathrm{LH}$ & 22.1 & 16.9 & 17.8 & 20.5 & 15.1 & 21.8 & 16.3 & 20.7 & 18.4 & $18.8 \pm 2.5 \%$ \\
\hline FSH & 48.3 & 45.2 & 59.7 & 51.4 & 49.5 & 50.3 & 52.9 & 57.1 & 44.8 & $51.0 \pm 5.0 \%$ \\
\hline TSH & 39.6 & 30.3 & 35.2 & 25.7 & 22.5 & 24.8 & 27.4 & 29.1 & 33.8 & $29.8 \pm 5.5 \%$ \\
\hline NeuroD1 & 59.94 & 44.46 & 85.03 & 77.73 & 76.65 & 73.12 & 90.22 & 14.0 & 87.96 & $67.7 \pm 24.8 \%$ \\
\hline
\end{tabular}


Figure 12: Percentage of Neuro D1 expressing cells in the adenohypophysis of patients without pituitary pathology. 




Figure 13: Double stain immunohistochemistry, normal anterior pituitary, Growth hormone/NeuroD1, $\times$ 400. Growth hormone is visualized with red colour, NeuroD1 with blue colour. Co-expression (Growth hormone and NeuroD1) is seen in $80 \%$ of cells (in this photo; indicated by arrows). GH/NeuroD1 same cell co-expression was $45 \%$, on average in this case.

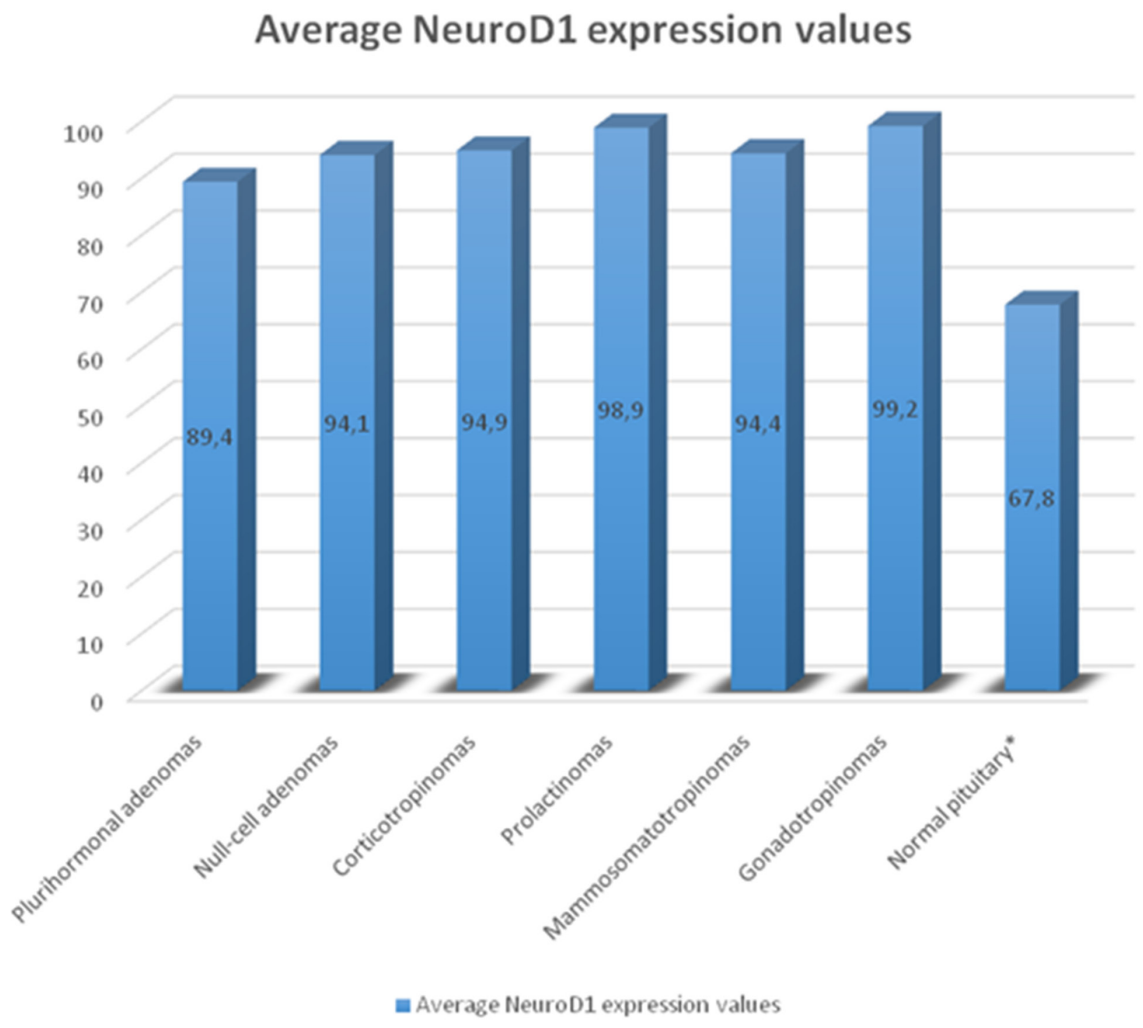

Figure 14: Average number of NeuroD1 expressing cells in normal adenohypophysis specimens and adenomas. Significant differences in Neuro D1 values between the normal adenohypophysis group and adenoma groups marked with an asterisk. 


\section{DISCUSSION}

In this study, we performed immunodetection of NeuroD1 in various types of pituitary adenomas. Using immunohistochemistry, we have shown that NeuroD1 is expressed not only incorticotropinomas, but in fact in all study samples, including plurihormonal and null-cell pituitary adenomas, prolactinomas, somatotropinomas, mammosomatotropinomas, and gonadotropinomas. In fact, the expressing cell average was $96 \%$ in the



Figure 15: Correlation values between the average numbers of cells with hormone, Neuro D1 and Ki-67 expression in the pituitary gland; $p>0.05$.



Figure 16: Mean Ki-67 values in different pituitary adenoma groups. 
Table 4: Patient clinical characteristics and methodological details

\begin{tabular}{|c|c|c|c|c|c|c|c|}
\hline № & Sex & Age & $\begin{array}{l}\text { Patient pituitary adenoma } \\
\text { type, according to IHC or } \\
\text { comorbid conditions in } \\
\text { normal pituitary donors } \\
\text { (autopsy) with duration }\end{array}$ & $\begin{array}{c}\text { Type of pituitary } \\
\text { adenoma, according } \\
\text { to clinical data } \\
\text { or corticosteroid, } \\
\text { antineoplasic drug } \\
\text { history (autopsies) }\end{array}$ & $\begin{array}{l}\text { Proximal } \\
\text { cause of } \\
\text { death and } \\
\text { duration of } \\
\text { that cause }\end{array}$ & $\begin{array}{l}\text { Adenoma or } \\
\text { normal pituitary } \\
\text { dimensions (in } \\
\text { mm, by MRI or } \\
\text { autopsy) }\end{array}$ & $\begin{array}{c}\text { Methods } \\
\text { applied }\end{array}$ \\
\hline 1 & $\mathrm{~F}$ & 43 & Plurihormonal adenoma & Corticotropinoma & - & $22 \times 19 \times 15$ & $\mathrm{H}, \mathrm{IHC}$ \\
\hline 2 & $\mathrm{~F}$ & 69 & Plurihormonal adenoma & Somatotropinoma & - & $5 \times 6 \times 8$ & $\mathrm{H}, \mathrm{IHC}$ \\
\hline 3 & $\mathrm{~F}$ & 40 & Plurihormonal adenoma & $\begin{array}{c}\text { Hormone-inactive } \\
\text { adenoma }\end{array}$ & - & $12 \times 10 \times 11$ & $\mathrm{H}, \mathrm{IHC}$ \\
\hline 4 & $\mathrm{~F}$ & 40 & Plurihormonal adenoma & $\begin{array}{c}\text { Hormone-inactive } \\
\text { adenoma }\end{array}$ & - & $9 \times 6 \times 7$ & $\mathrm{H}, \mathrm{IHC}$ \\
\hline 5 & M & 30 & Plurihormonal adenoma & Prolactinoma & - & $25 \times 28 \times 18$ & $\mathrm{H}, \mathrm{IHC}$ \\
\hline 6 & $\mathrm{~F}$ & 35 & Plurihormonal adenoma & Corticotropinoma & - & $12 \times 12 \times 6$ & $\begin{array}{l}\mathrm{H}, \mathrm{IHC}, \\
\mathrm{DSIHC}\end{array}$ \\
\hline 7 & M & 41 & Plurihormonal adenoma & Somatotropinoma & - & $34 \times 42 \times 28$ & $\begin{array}{l}\text { H, IHC, } \\
\text { DSIHC }\end{array}$ \\
\hline 8 & M & 63 & Corticotropinoma & Corticotropinoma & - & $28 \times 23 \times 20$ & $\mathrm{H}, \mathrm{IHC}$ \\
\hline 9 & M & 37 & Corticotropinoma & Prolactinoma & - & $48 \times 45 \times 40$ & $\mathrm{H}, \mathrm{IHC}$ \\
\hline 10 & $\mathrm{~F}$ & 61 & Corticotropinoma & Corticotropinoma & - & $13 \times 12 \times 15$ & $\mathrm{H}, \mathrm{IHC}$ \\
\hline 11 & $\mathrm{~F}$ & 35 & Corticotropinoma & Corticotropinoma & - & $8 \times 7 \times 5,5$ & $\mathrm{H}, \mathrm{IHC}$ \\
\hline 12 & $\mathrm{~F}$ & 67 & Corticotropinoma & Corticotropinoma & - & $13 \times 10 \times 9$ & $\mathrm{H}, \mathrm{IHC}$ \\
\hline 13 & $\mathrm{~F}$ & 58 & Corticotropinoma & Corticotropinoma & - & $8 \times 6 \times 6$ & $\mathrm{H}, \mathrm{IHC}$ \\
\hline 14 & $\mathrm{~F}$ & 48 & Corticotropinoma & Corticotropinoma & - & $9 \times 7 \times 6$ & $\mathrm{H}, \mathrm{IHC}$ \\
\hline 15 & $\mathrm{~F}$ & 31 & Corticotropinoma & Corticotropinoma & - & $11,5 \times 6 \times 14$ & $\mathrm{H}, \mathrm{IHC}$ \\
\hline 16 & M & 48 & Mammosomatotropinoma & Somatotropinoma & - & $16 \times 14 \times 9$ & $\mathrm{H}, \mathrm{IHC}$ \\
\hline 17 & M & 42 & Mammosomatotropinoma & Somatotropinoma & - & $22 \times 15 \times 10$ & $\mathrm{H}, \mathrm{IHC}$ \\
\hline 18 & M & 30 & Mammosomatotropinoma & Somatotropinoma & - & $23 \times 19 \times 22$ & $\begin{array}{l}\text { H, IHC, } \\
\text { DSIHC }\end{array}$ \\
\hline 19 & M & 63 & Mammosomatotropinoma & Somatotropinoma & - & $12 \times 18 \times 19$ & $\begin{array}{l}\mathrm{H}, \mathrm{IHC}, \\
\mathrm{DSIHC}\end{array}$ \\
\hline 20 & $\mathrm{~F}$ & 57 & Mammosomatotropinoma & Prolactinoma & - & $15 \times 18 \times 14$ & $\mathrm{H}, \mathrm{IHC}$ \\
\hline 21 & M & 26 & Mammosomatotropinoma & Somatotropinoma & - & $34 \times 26 \times 39$ & $\begin{array}{l}\text { H, IHC, } \\
\text { CLSM }\end{array}$ \\
\hline 22 & $\mathrm{~F}$ & 64 & Mammosomatotropinoma & Somatotropinoma & - & $9 \times 13 \times 14$ & $\begin{array}{l}\text { H, IHC, } \\
\text { CLSM }\end{array}$ \\
\hline 23 & $\mathrm{~F}$ & 58 & Mammosomatotropinoma & Somatotropinoma & - & $9 \times 2 \times 7$ & $\begin{array}{l}\text { H, IHC, } \\
\text { CLSM }\end{array}$ \\
\hline 24 & $\mathrm{~F}$ & 39 & Mammosomatotropinoma & Somatotropinoma & - & $18 \times 14 \times 13$ & $\begin{array}{l}\mathrm{H}, \mathrm{IHC} \\
\mathrm{EICC}\end{array}$ \\
\hline 25 & $\mathrm{~F}$ & 20 & Mammosomatotropinoma & Prolactinoma & - & $22 \times 21 \times 19$ & $\begin{array}{l}\mathrm{H}, \mathrm{IHC} \\
\mathrm{EICC}\end{array}$ \\
\hline 26 & M & 68 & Prolactinoma & Prolactinoma & - & $30 \times 33 \times 35$ & $\begin{array}{l}\mathrm{H}, \mathrm{IHC} \\
\text { (Continue }\end{array}$ \\
\hline
\end{tabular}




\begin{tabular}{|c|c|c|c|}
\hline № & Sex & Age & $\begin{array}{l}\text { Patient pituitary adenoma } \\
\text { type, according to IHC or } \\
\text { comorbid conditions in } \\
\text { normal pituitary donors } \\
\text { (autopsy) with duration }\end{array}$ \\
\hline
\end{tabular}

$\begin{array}{cc}\text { Type of pituitary } & \text { Proximal } \\ \text { adenoma, according } & \begin{array}{c}\text { cause of } \\ \text { to clinical data }\end{array} \\ \text { or corticosteroid, } & \begin{array}{c}\text { duration of } \\ \text { that cause }\end{array} \\ \text { antineoplasic drug } \\ \text { history (autopsies) }\end{array}$

Adenoma or
normal pituitary
dimensions (in
mm, by MRI or
autopsy)

Methods

applied

\begin{tabular}{|c|c|c|c|c|c|c|c|}
\hline 27 & $\mathrm{~F}$ & 40 & Prolactinoma & Prolactinoma & - & $19 \times 16 \times 12$ & $\mathrm{H}, \mathrm{IHC}$ \\
\hline 28 & $\mathrm{~F}$ & 53 & Prolactinoma & Prolactinoma & - & $16 \times 17 \times 10$ & $\mathrm{H}, \mathrm{IHC}$ \\
\hline 29 & $\mathrm{~F}$ & 51 & Prolactinoma & Prolactinoma & - & $27 \times 37 \times 32$ & $\mathrm{H}, \mathrm{IHC}$ \\
\hline 30 & $\mathrm{~F}$ & 61 & Prolactinoma & $\begin{array}{c}\text { Hormone-inactive } \\
\text { adenoma }\end{array}$ & - & $22 \times 27 \times 19$ & $\mathrm{H}, \mathrm{IHC}$ \\
\hline 31 & $\mathrm{~F}$ & 40 & Prolactinoma & Prolactinoma & - & $9 \times 6 \times 7$ & $\mathrm{H}, \mathrm{IHC}$ \\
\hline 32 & M & 27 & Prolactinoma & Prolactinoma & - & $17 \times 25 \times 26$ & $\begin{array}{l}\text { H, IHC } \\
\text { DSIHC }\end{array}$ \\
\hline 33 & M & 56 & Prolactinoma & $\begin{array}{c}\text { Hormone-inactive } \\
\text { adenoma }\end{array}$ & - & $25 \times 29 \times 20$ & $\begin{array}{l}\mathrm{H}, \mathrm{IHC} \\
\text { DSIHC }\end{array}$ \\
\hline 34 & $\mathrm{~F}$ & 34 & Somatotropinoma & Somatotropinoma & - & $7 \times 9 \times 11$ & $\begin{array}{l}\mathrm{H}, \mathrm{IHC} \\
\text { EICC }\end{array}$ \\
\hline 35 & $\mathrm{~F}$ & 46 & Somatotropinoma & Somatotropinoma & - & $16 \times 13 \times 19$ & $\begin{array}{r}\mathrm{H}, \mathrm{IHC} \\
\text { EICC }\end{array}$ \\
\hline 36 & $\mathrm{~F}$ & 62 & Gonadotropinoma & $\begin{array}{c}\text { Hormone - inactive } \\
\text { adenoma }\end{array}$ & - & $19 \times 24 \times 17$ & $\mathrm{H}, \mathrm{IHC}$ \\
\hline 37 & $\mathrm{~F}$ & 71 & Gonadotropinoma & $\begin{array}{c}\text { Hormone - inactive } \\
\text { adenoma }\end{array}$ & - & $24 \times 28 \times 34$ & $\mathrm{H}, \mathrm{IHC}$ \\
\hline 38 & $\mathrm{~F}$ & 65 & Gonadotropinoma & $\begin{array}{c}\text { >Hormone - inactive } \\
\text { adenoma }\end{array}$ & - & $21 \times 22 \times 20$ & $\mathrm{H}, \mathrm{IHC}$ \\
\hline 39 & $\mathrm{M}$ & 62 & Gonadotropinoma & $\begin{array}{c}\text { Hormone - inactive } \\
\text { adenoma }\end{array}$ & - & $14 \times 19 \times 9$ & $\mathrm{H}, \mathrm{IHC}$ \\
\hline 40 & $\mathrm{~F}$ & 63 & Gonadotropinoma & $\begin{array}{c}\text { Hormone - inactive } \\
\text { adenoma }\end{array}$ & - & $27 \times 18 \times 24$ & $\mathrm{H}, \mathrm{IHC}$ \\
\hline 41 & $\mathrm{~F}$ & 54 & Null-cell adenoma & $\begin{array}{c}\text { Hormone - inactive } \\
\text { adenoma }\end{array}$ & - & $21 \times 25 \times 26$ & $\mathrm{H}, \mathrm{IHC}$ \\
\hline 42 & $\mathrm{~F}$ & 66 & Null-cell adenoma & $\begin{array}{c}\text { Hormone - inactive } \\
\text { adenoma }\end{array}$ & - & $15 \times 6 \times 9$ & $\mathrm{H}, \mathrm{IHC}$ \\
\hline 43 & $\mathrm{~F}$ & 44 & Null-cell adenoma & $\begin{array}{c}\text { Hormone - inactive } \\
\text { adenoma }\end{array}$ & - & $20 \times 17 \times 19$ & $\mathrm{H}, \mathrm{IHC}$ \\
\hline 44 & $\mathrm{M}$ & 74 & Null-cell adenoma & $\begin{array}{c}\text { Hormone - inactive } \\
\text { adenoma }\end{array}$ & - & $44 \times 47 \times 43$ & $\mathrm{H}, \mathrm{IHC}$ \\
\hline 45 & $\mathrm{M}$ & 14 & Null-cell adenoma & $\begin{array}{c}\text { Hormone - inactive } \\
\text { adenoma }\end{array}$ & - & $38 \times 41 \times 59$ & $\mathrm{H}, \mathrm{IHC}$ \\
\hline 46 & $\mathrm{M}$ & 69 & Null-cell adenoma & $\begin{array}{c}\text { Hormone - inactive } \\
\text { adenoma }\end{array}$ & - & $30 \times 24 \times 27$ & $\mathrm{H}, \mathrm{IHC}$ \\
\hline 47 & $\mathrm{~F}$ & 67 & Null-cell adenoma & $\begin{array}{c}\text { Hormone - inactive } \\
\text { adenoma }\end{array}$ & - & $19 \times 12 \times 15$ & $\mathrm{H}, \mathrm{IHC}$ \\
\hline 48 & $\mathrm{~F}$ & 70 & Null-cell adenoma & $\begin{array}{c}\text { Hormone - inactive } \\
\text { adenoma }\end{array}$ & - & $53 \times 50 \times 37$ & $\mathrm{H}, \mathrm{IHC}$ \\
\hline
\end{tabular}




\begin{tabular}{|c|c|c|c|c|c|c|c|}
\hline № & Sex & Age & $\begin{array}{l}\text { Patient pituitary adenoma } \\
\text { type, according to IHC or } \\
\text { comorbid conditions in } \\
\text { normal pituitary donors } \\
\text { (autopsy) with duration }\end{array}$ & $\begin{array}{l}\text { Type of pituitary } \\
\text { adenoma, according } \\
\text { to clinical data } \\
\text { or corticosteroid, } \\
\text { antineoplasic drug } \\
\text { history (autopsies) }\end{array}$ & $\begin{array}{l}\text { Proximal } \\
\text { cause of } \\
\text { death and } \\
\text { duration of } \\
\text { that cause }\end{array}$ & $\begin{array}{c}\text { Adenoma or } \\
\text { normal pituitary } \\
\text { dimensions (in } \\
\text { mm, by MRI or } \\
\text { autopsy) }\end{array}$ & $\begin{array}{l}\text { Methods } \\
\text { applied }\end{array}$ \\
\hline 49 & M & 65 & $\begin{array}{c}\text { Normal pituitary (autopsy) } \\
\text { Dilated cardiomyopathy (65 } \\
\text { years) }\end{array}$ & $\begin{array}{l}\text { No use of } \\
\text { corticosteroid or } \\
\text { anticancer drugs }\end{array}$ & $\begin{array}{l}\text { Heart failure } \\
\text { (3 years) }\end{array}$ & $11 \times 10 \times 7$ & $\begin{array}{l}\text { H, IHC, } \\
\text { DSIHC }\end{array}$ \\
\hline 50 & M & 68 & $\begin{array}{c}\text { Normal pituitary (autopsy) } \\
\text { Coronary artery disease ( } 5 \\
\text { years) }\end{array}$ & $\begin{array}{l}\text { No use of } \\
\text { corticosteroid or } \\
\text { anticancer drugs }\end{array}$ & $\begin{array}{l}\text { Myocardial } \\
\text { infarction ( } 3 \\
\text { days) }\end{array}$ & $11 \times 8 \times 7$ & $\mathrm{H}, \mathrm{IHC}$ \\
\hline 51 & $\mathrm{~F}$ & 28 & $\begin{array}{c}\text { Normal pituitary (autopsy) Left } \\
\text { ventricular noncompaction ( } 28 \\
\text { years) }\end{array}$ & $\begin{array}{l}\text { No use of } \\
\text { corticosteroid or } \\
\text { anticancer drugs }\end{array}$ & $\begin{array}{l}\text { Pulmonary } \\
\text { embolism } \\
(<1 \text { day })\end{array}$ & $9 \times 6 \times 5$ & $\mathrm{H}, \mathrm{IHC}$ \\
\hline 52 & M & 41 & $\begin{array}{l}\text { Normal pituitary (autopsy) } \\
\text { Aortic valve disease (41 years) }\end{array}$ & $\begin{array}{l}\text { No use of } \\
\text { corticosteroid or } \\
\text { anticancer drugs }\end{array}$ & $\begin{array}{l}\text { Heart failure } \\
\text { (1 year) }\end{array}$ & $13 \times 6 \times 6$ & $\mathrm{H}, \mathrm{IHC}$ \\
\hline 53 & M & 55 & $\begin{array}{c}\text { Normal pituitary (autopsy) } \\
\text { Dilated cardiomyopathy ( } 55 \\
\text { years) }\end{array}$ & $\begin{array}{l}\text { No use of } \\
\text { corticosteroid or } \\
\text { anticancer drugs }\end{array}$ & $\begin{array}{l}\text { Heart failure } \\
\text { (4.5years) }\end{array}$ & $12 \times 7 \times 7$ & $\mathrm{H}, \mathrm{IHC}$ \\
\hline 54 & $\mathrm{~F}$ & 19 & $\begin{array}{l}\text { Normal pituitary (autopsy) } \\
\text { Leukemia (11 months) }\end{array}$ & $\begin{array}{c}\text { cytarabine and } \\
\text { daunorubicin; } \\
\text { without corticosteroid } \\
\text { use }\end{array}$ & $\begin{array}{l}\text { Pneumonia } \\
\text { (7 days) }\end{array}$ & $9 \times 8 \times 6$ & $\mathrm{H}, \mathrm{IHC}$ \\
\hline 55 & M & 63 & $\begin{array}{l}\text { Normal pituitary (autopsy) } \\
\text { Aortic valve disease (10 years) }\end{array}$ & $\begin{array}{l}\text { No use of } \\
\text { corticosteroid or } \\
\text { anticancer drugs }\end{array}$ & $\begin{array}{l}\text { Heart failure } \\
\text { (1.5 year) }\end{array}$ & $10 \times 8 \times 7$ & $\mathrm{H}, \mathrm{IHC}$ \\
\hline 56 & $\mathrm{~F}$ & 48 & $\begin{array}{l}\text { Normal pituitary (autopsy) } \\
\text { Uterine cancer (radical } \\
\text { hysterectomy and radiotherapy } \\
5 \text { years prior) }\end{array}$ & $\begin{array}{l}\text { No use of } \\
\text { corticosteroid or } \\
\text { anticancer drugs }\end{array}$ & $\begin{array}{l}\text { Cancer } \\
\text { intoxication } \\
\text { (1 year) }\end{array}$ & $9 \times 7 \times 6$ & $\mathrm{H}, \mathrm{IHC}$ \\
\hline 57 & M & 69 & $\begin{array}{c}\text { Normal pituitary (autopsy) } \\
\text { Coronary artery disease ( } 9 \\
\text { years) }\end{array}$ & $\begin{array}{l}\text { No use of } \\
\text { corticosteroid or } \\
\text { anticancer drugs }\end{array}$ & $\begin{array}{c}\text { Myocardial } \\
\text { infarction }(< \\
1 \text { day })\end{array}$ & $11 \times 9 \times 8$ & $\mathrm{H}, \mathrm{IHC}$ \\
\hline
\end{tabular}

H: histology; IHC: immunohistochemistry; DSIHC: double stain immunohistochemistry; CLSM: confocal laser scanning microscopy; EICC: electron immunocytochemistry; MRI: magnetic resonance imaging.

entire study. A number of methods were used to clarify NeuroD1's expression status. In prolactinomas, expression was confirmed by double stain immunohistochemistry. In mammosomatotropinomas, double stain immunohistochemistry and confocal laser scanning microscopy were used. Electron immunocytochemistry was used to evaluate somatotropinomas.

The data we have acquired are in contrast with a series of pituitary adenoma studies and concepts of pituitary gland embryogenesis $[18,19,20]$. However, NeuroD1 expression has, in fact, been detected in the nullcell pituitary adenomas [21]. NeuroD1 expression levels were notably higher in "silent" corticotropinomas [22].
Ferretti et al. [23] found NeuroD1 in all types of pituitary adenomas, but not in all cases. Takiguchi et al. revealed significant expression of NeuroD1 and Pit-1 mRNA in plurihormonal adenomas secreting ACTH and GH [24]. NeuroD1 protein has been detected in the nucleus of nontumorous anterior pituitary cells, with localization mainly in corticotroph cells which process proopiomelanocortin into ACTH [25].

On the one hand, we have also detected NeuroD1 in normal pituitary cells; on the other hand, the results of our previous investigation proved that normal pituitary cells are plurihormonal [26]. The present work shows that this $\mathrm{TF}$ is not only expressed in ACTH-expressing cells. The 
same results were obtained with normal adenohypophysis taken near adenoma boundaries. Earlier, NeuroD1's role was understood to be solely connected with the process of embryonic corticotroph formation [27]. However, the data we present suggest that NeuroD1 likely has additional roles. Its widespread expression, in various tissue types, supports this idea.

It should be noted that, like our study, relatively higher NeuroD1 expression levels in adenomas, compared to normal pituitary, have been demonstrated by Fratticci et al. [28]. Such differences in NeuroD1 expression levels in adenomas versus in normal glands may point to a significant role in tumorigenesis. Interestingly, in terms of the average numbers of pituicytes expressing the transcription factor, normal pituitary specimens taken near adenoma boundaries were comparable to adenomas and were much higher than in the normal adenohypophysis (control group). However, the differences we observed between the average number of NeuroD1 expressing cells in normal adenohypophysis fragments near adenoma boundaries and in normal pituitary gland did not reach the statistical significance. This fact can be explained by the small number of cases (4) which were available for the study. This finding implies that NeuroD1 may play key roles in adenoma tumor development or recurrence.

NeuroD1 is expressed not only in the pituitary gland, but also in pancreatic precursor cells, which subsequently differentiate into pancreatic endocrine cells [29, 30]. In addition, NeuroD1 has been detected in the neuroectoderm cells [31]. Moreover, the transcription factor participates in the activation of various genes in adult endocrine, enteroendocrine and neuroendocrine cells; these cells may secrete insulin-1 [32, 33], glucokinase [34], secretin [35], and/or inositol 1,4,5-trisphosphate receptor (IP3R1) [36]. NeuroD1 also plays an important role in the differentiation, morphogenesis, and normal functioning of central nervous system cells [37].

Tani et al. [38] found that NeuroD1 levels were comparable between carcinoid tumors causing ectopic ACTH syndrome and pituitary tumors causing Cushing's disease. This fact indicates that NeuroD1's role in pathogenesis may not be limited to only pituitary tumors; it may play roles in other neuroendocrine tumors as well. The wide range of functions described in the literature for this TF indicate that it is of particular significance. NeuroD1's consistently high expression levels in all types of pituitary adenomas make it an attractive potential target for new drugs designed to reduce its expression. Ideally, such a NeuroD1-targeting drug could be used for the treatment of aggressive or recurrent neuroendocrine tumor cases. The success of such a drug would be predicated on its ability to reduce NeuroD1 expression to levels near those seen in the normal pituitary gland.

Given the fact that NeuroD1 levels are significantly higher in pituitary adenomas than in normal pituitary gland, this protein may be a prognostic factor. In this study, we did not see significant correlation between NeuroD1 and Ki-67 expression in tumor cells. In our opinion, this can be explained by the fact that Ki-67 is neither an ideal indicator nor a sole predictor for pituitary adenoma. This view is supported by de Aguiar et al. [39]. Salehi et al. [40] suggest that inconsistencies in data regarding $\mathrm{Ki}-67$ 's role in tumors may be due to differences in the ways in which different research groups study tumors and their manifestations. In particular, the research methodologies used for tumor study are have not been standardized. Different authors use varying criteria of tumor invasion and recurrence. Zakir et al. [41] suggest using several prognostics markers simultaneously, not simply by Ki-67 alone. Such a multiplex approach seems appropriate in light of the complexity of the situation.

\section{MATERIALS AND METHODS}

\section{Clinical samples}

48 pituitary adenomas and 9 normal pituitary glands were studied. Adenomas were removed by endoscopictranssphenoidal surgery and they represented a variety of tumor types ( 7 plurihormonal adenomas, 8 corticotropinomas, 10 mammosomatotropinomas, 8 prolactinomas, 2 somatotropinomas, 5 gonadotropinomas, and 8 null-cell adenomas). Normal pituitary glands were obtained from patients who died from cardiovascular or oncological diseases. Pituitary glands were taken within 4 hours after death. None of the patients were treated with prolonged corticosteroids, antineoplastic drugs, or other treatments that affect endocrine status or function of the pituitary. A patient with leukemia (acute myeloblastic leukemia) received induction chemotherapy with cytarabine and daunorubicin ("7 + 3") and did not receive hormone therapy. The patient did not have neuroleukemia; clinically, her pituitary function was not impaired. Patients with pituitary adenomas were aged from 14 to 74 years ( $50 \pm 15$ years on average), and the group comprised 32 women and 16 men. The control group (normal pituitary) was comprised of 5 women and 4 men; the mean age was $58 \pm 11.7$ years, and the ages ranged from 33 to 73 years old. Histological study included hematoxylin and eosin staining, PAS-reaction, and the Gordon-Sweet silver staining methods. Table 4 summarizes data on the clinical characteristics of the patients included in the study, as well as the specific methods used to study samples.

\section{Antibodies}

For immunohistochemical staining, confocal microscopy, and electron immunocytochemistry, the following primary antibodies were used: 
mouse monoclonal ACTH antibody, diluted 1:500 (clone AH26, Diagnostic BioSystems, Netherlands) USA) rabbit polyclonal TSH antibody, RTU (Cell Marque, mouse monoclonal FSH antibody, diluted 1:100 (clone C10, DAKO, Denmark) mouse monoclonal LH antibody, diluted 1:500 (clone C93, DAKO, Denmark) rabbitpolyclonal GH antibody, diluted 1:100 (BioGenex, USA) rabbit polyclonal PRL antibody, diluted 1:700 (DAKO, Denmark) mouse monoclonal NeuroD1 antibody, diluted 1:1000 (clone ab60704, Abcam, United Kingdom) mouse monoclonal Ki-67antibody, diluted 1:200 (clone MIB-1, DAKOCytomation, Denmark) mouse monoclonal CK7antibody, diluted 1:300 (clone OV-TL 12/30, DAKO, Denmark)

The following secondary antibodies/reagents were used for immunohistochemical staining: mouse EnVision ${ }^{\mathrm{TM}}+$ System, Peroxidase (DAKO, Denmark) Denmark) rabbit EnVision ${ }^{\mathrm{TM}}+$ System, Peroxidase (DAKO, UK) MultiVision Polymer Cocktail (Thermo Scientific,

The following secondary antibodies were used for confocal microscopy:

Alexa Fluor 647 goat anti-Mouse, diluted 1:100 (Abcam, UK)

Alexa Fluor 488 goat anti-Rabbit, diluted 1:100 (Abcam, UK)

The following secondary antibodies were used for electron immunocytochemistry:

goat-anti mouse antibody conjugated to $10 \mathrm{~nm}$ colloidal gold, diluted 1:100 (Sigma-Aldrich, US)

goat-anti rabbit antibody conjugated to $5 \mathrm{~nm}$ colloidal gold, diluted 1:100 (Sigma-Aldrich, US)

\section{Immunohistochemistry}

For all samples, immunohistochemical study of paraffin sections, using peroxidase-based detection, was performed by one step primary staining with antibodies to NeuroD1, growth hormone (GH), prolactin (PRL), thyroid-stimulating hormone (TSH), adrenocorticotropic hormone $(\mathrm{ACTH})$, luteinizing hormone $(\mathrm{LH})$, folliclestimulating hormone (FSH), Ki-67, and CK7. Additionally, immunohistochemical double-staining (GH/NeuroD1 and PRL/NeuroD1 cocktails) was used in 2 cases of plurihormonal adenoma, in 2 prolactinomas, in 2 mammosomatotropinomas, and in 1 normal pituitary sample. In order to verify that vendor anti-Neuro D1 antibodies are specific to the D1 isoform of the transcription factor, we performed immunohistochemical staining (anti-Neuro D1) of skeletal muscle sections as a negative control; the muscle section stainings were completely negative (Supplementary Figure 2). The complete immunohistohemical staining method, as used here, is provided in the Supplementary Materials.

\section{Confocal laser scanning microscopy}

In 4 mammosomatotropinomas, confocal laser scanning microscopy (Olympus FV1000D, Japan) was performed using the same primary antibodies $(\mathrm{GH} /$ NeuroD1 and PRL/NeuroD1 cocktail). Alexa Fluor 488 goat anti-rabbit and Alexa Fluor 647 goat anti-mouse (Abcam, UK) were used as secondary antibodies. Nuclei were stained with DAPI (appliChem). Details of the confocal laser scanning microscopy method are given in the Supplementary Materials.

\section{Electron immunocytochemistry}

Electron immunocytochemistry was performed as a post-embedding procedure on ultrathin sections of LR White-embedded specimens, with indirect immunolabelling of protein of interest. NeuroD1 immunodetection by electron immunocytochemistry was performed on 2 mammosomatotropinomas, and electron immunocytochemistry with double detection (NeuroD1 and $\mathrm{GH}$ ) was performed on 2 somatotropinomas (Table 4). The complete procedure is provided in the Supplementary Materials.

\section{Morphometry and statistics}

Morphometric analysis was performed using an automated image analyzer (Image Scope Color M, Russia). In order to analyze the relative quantities of cells expressing select antigens, 10 high power fields (400x magnification) were evaluated per specimen. For all of the hormones and NeuroD1, percentages of the average number of expressing cells, in relation to overall pituicytes, were separately calculated. In addition, percentages of the average number of of cells co-expressing two markers, in relation to overall pituicytes, were calculated, as follows: $(\mathrm{GH}+\mathrm{NeuroD} 1) /$ total or $(\mathrm{PRL}+\mathrm{NeuroD} 1) /$ total.

Statistical analysis of the acquired data was done using Statistica v.10 software (StatSoft, Russia). For normal distributions, the significance of differences in quantitative characteristics was interpreted using the Student's $t$-test. For other types of distribution, we used non-parametric methods of analysis, namely the Mann-Whitney test for independent samples and the Wilcoxon test. Differences between groups were defined as significant when $p<0.05$.

In order to evaluate the correlation of two variables, we applied Spearman rank correlation analysis. Correlation coefficient ( $r$ ) interpretation: $r<0.3$ : weak association; $r=0.3-0.5$ : moderate; $r=0.5-0.7$ : significant; 
$r=0.7-0.9$ : strong; and $r>0.9$ : very strong. Correlation was considered as positive if $r>0$ and negative if $r<0$.

\section{CONCLUSIONS}

Data from a number of methods (immunohisto chemistry, confocal microscopy, and double label electron immunocytochemistry) suggest that NeuroD1 plays a key role in the pathogenesis of pituitary tumors, regardless of their hormonal state. This transcription factor is expressed at substantial levels in $96 \%$ of tumor cells, on average. Its expression level in pituitary adenomas is significantly higher than in the normal pituitary gland and has no reliable correlation with any other study hormones or Ki-67. In our opinion, NeuroD1's consistently high expression levels in all pituitary adenoma types make it an attractive potential target for new drugs. If drugs can be designed or screened which reduce NeuroD1 expression to levels near those seen in the normal pituitary gland, such drugs could be vital in the treatment of aggressive neuroendocrine tumors or in the prevention of their reoccurrence.

\section{Author contributions}

Lubov Mitrofanova: conceptualization; methodology and design; acquisition and interpretation of the data; histological and immunohistochemical study; drafting the manuscript; critical revision of content. Olga Vorobeva: histological and immunohistochemical study; analysis and interpretation of the data; electron microscopy; software statistical analysis. Andrey Gorshkov: laser confocal microscopy; electron immunocytochemistry; analysis and interpretation of the data.

\section{ACKNOWLEDGMENTS}

The authors thank Edward Ramsay for his assistance with writing and editing. The authors express particular gratitude to professor Igor Kvetnoy, M.D., (Head, Department of Pathology, Ott Research Institute of Obstetrics, Gynaecology and Reproductology) for kindly providing access to confocal microscopy facilities. The authors also thank Boris Galkovsky for technical support, Valeria Rodichkina for her assistance in the confocal microscopy process.

\section{CONFLICTS OF INTEREST}

The authors declare that they have no conflicts of interest.

\section{GRANT SUPPORT}

None.

\section{REFERENCES}

1. Mete O, Lopes MB. Overview of the 2017 WHO classification of pituitary tumors. Endocr Pathol. 2017; 28:228-243. https://doi.org/10.1007/s12022-017-9498-z.

2. Mooney MA, Simon ED, Little AS. Advancing treatment of pituitary adenomas through targeted molecular therapies: the acromegaly and cushing disease paradigms. Front Surg. 2016; 3:45. https://doi.org/10.3389/fsurg.2016.00045.

3. Starke RM, Raper DM, Payne SC, Vance ML, Oldfield EH, Jane JA Jr. Endoscopic vs microsurgical transsphenoidal surgery for acromegaly: outcomes in a concurrent series of patients using modern criteria for remission. J Clin Endocrinol Metab. 2013; 98: 3190-3198. https://doi.org/10.1210/jc.2013-1036.

4. Shin SS, Tormenti MJ, Paluzzi A, Rothfus WE, Chang YF, Zainah H, Fernandez-Miranda JC, Snyderman $\mathrm{CH}$, Challinor SM, Gardner PA. Endoscopic endonasal approach for growth hormone secreting pituitary adenomas: outcomes in 53 patients using 2010 consensus criteria for remission. Pituitary. 2013; 16:435-444. https://doi.org/10.1007/s11102-012-0440-6.

5. Fleseriu M, Delashaw JB Jr, Cook DM. Acromegaly: a review of current medical therapy and new drugs on the horizon. Neurosurg Focus. 2010; 29:E15. https://doi.org/10.3171/2010.7.FOCUS10154.

6. Bronstein MD. Acromegaly: molecular expression of somatostatin receptor subtypes and treatment outcome. Front Horm Res. 2006; 35:129-134. https://doi.org/10.1159/000094315.

7. Kopchick JJ, Parkinson C, Stevens EC, Trainer PJ. Growth hormone receptor antagonists: discovery, development, and use in patients with acromegaly. Endocr Rev. 2002; 23:623646. https://doi.org/10.1210/er.2001-0022.

8. Suhardja A, Kovacs K, Rutka J. Role of transcription factors in the pathogenesis of pituitary adenomas: a review. J Neurooncol. 2001; 55:185-193.

9. Asa SL. Tumors of the pituitary gland. AFIP Atlas of Tumor Pathology. ARP Press: Washington; 2011. 283p.

10. Al-Brahim NY, Asa SL. My approach to pathology of the pituitary gland. J Clin Pathol 2006; 59:1245-1253. https://doi.org/10.1136/jcp.2005.031187.

11. Naya FJ, Huang HP, Qiu Y, Mutoh H, DeMayo FJ, Leiter AB, Tsai MJ. Diabetes, defective pancreatic morphogenesis, and abnormal enteroendocrine differentiation in BETA2/ neuroD-deficient mice. Genes Dev. 1997; 11:2323-2334. https://doi.org/10.1101/gad.11.18.2323.

12. Seltzer J, Ashton C, Scotton TC, Pangal D, Carmichael JD, Zada G. Gene and protein expression in pituitary corticotroph adenomas: a systematic review of the literature. Neurosurg Focus. 2015; 38:E17. https://doi.org/10.3171/2014.10.FOCUS14683.

13. Hevner RF, Hodge RD, Daza RA, Englund C. Transcription factors in glutamatergic neurogenesis: 
conserved programs in neocortex, cerebellum, and adult hippocampus. Neurosci Res. 2006; 55:223-233. https://doi.org/10.1016/j.neures.2006.03.004.

14. Aprea J, Nonaka-Kinoshita M, Calegari F. Generation and characterization of Neurod1-CreER(T2) mouse lines for the study of embryonic and adult neurogenesis. Genesis 2014; 52:870-878. https://doi.org/10.1002/dvg.22797.

15. Vierbuchen T, Ostermeier A, Pang ZP, Kokubu Y, Sudhof TC, Wernig M. Direct conversion of fibroblasts to functional neurons by defined factors. Nature.2010; 463:1035-1041. https://doi.org/10.1038/nature08797.

16. Guo Z, Zhang L, Wu Z, Chen Y, Wang F, Chen G. in vivo direct reprogramming of reactive glial cells into functional neurons after brain injury and in an Alzheimer's disease model. Cell Stem Cell. 2014; 14:188-202. https://doi.org/10.1016/j.stem.2013.12.001.

17. Pataskar A, Jung J, Smialowski P, Noack F, Calegari F, Straub T, Tiwari VK. NeuroD1 reprograms chromatin and transcription factor landscapes to induce the neuronal program. EMBO J. 2016; 35:24-45. https://doi.org/10.15252/embj.201591206.

18. Lloyd RV, Jin L, Chandler WF, Horvath E, Stefaneanu L, Kovacs K. Pituitary specific transcription factor messenger ribonucleic expression in adenomatous and nontumorous human pituitary tissues. Lab Invest. 1993; 69:570-575.

19. Osamura RY, Tahara S, Kurotani R, Sanno N, Matsuno A, Teramoto A. Contributions of immunohistochemistry and in situ hybridization to the functional analysis of pituitary adenomas. J Histochem Cytochem. 2000; 48:445-458. https://doi.org/10.1177/002215540004800401.

20. Lamolet B, Pulichino AM, Lamonerie T, Gauthier Y, Brue T, Enjalbert A, Drouin J. A pituitary cell-restricted T box factor, Tpit, activates POMC transcription in cooperation with Pitx homeoproteins. Cell. 2001; 104:849-859. https://doi.org/10.1016/s0092-8674(01)00282-3.

21. Oyama K, Sanno N, Teramoto A, Osamura RY. Expression of Neuro D1 in human normal pituitaries and pituitary adenomas. Mod Pathol. 2001; 14:892-899. https://doi.org/10.1038/modpathol.3880408..

22. Tateno T, Izumiyama H, Doi M, Yoshimoto T, Shichiri M, Inoshita N, Oyama K, Yamada S, Hirata Y. Differential gene expression in ACTH-secreting and non-functioning pituitary tumors. Eur J Endocrinol. 2007; 157:717-724. https://doi.org/10.1530/EJE-07-0428.

23. Ferretti E, Di Stefano D, Zazzeroni F, Gallo R, Fratticci A, Carfagnini R, Angiulli S, Santoro A, Minniti G, Tamburrano G, Alesse E, Cantore G, Gulino A, Jaffrain-Rea ML. Human pituitary tumours express the bHLH transcription factors NeuroD1 and ASH1. J Endocrinol Invest. 2003; 26:957965. https://doi.org/10.1007/BF03348192.

24. Takiguchi T, Koide H, Nagano H, Nakayama A, Fujimoto M, Tamura A, Komai E, Shiga A, Kono T, Higuchi S, Sakuma I, Hashimoto N, Suzuki S, et al. Multihormonal pituitary adenoma concomitant with Pit-1 and Tpit lineage cells causing acromegaly associated with subclinical Cushing's disease: a case report. BMC Endocr Disord. 2017; 17:54. https://doi.org/10.1186/s12902-017-0203-5.

25. Poulin G, Turgeon B, Drouin J. NeuroD1/beta2 contributes to cell-specific transcription of the proopiomelanocortin gene. Mol Cell Biol. 1997; 17:6673-6682. https://doi.org/10.1128/mcb.17.11.6673.

26. Mitrofanova LB, Konovalov PV, Krylova JS, Polyakova VO, Kvetnoy IM. Plurihormonal cells of normal anterior pituitary: Facts and conclusions. Oncotarget. 2017; 8:29282-29299. https://doi.org/10.18632/oncotarget.16502.

27. Lamolet B, Poulin G, Chu K, Guillemot F, Tsai M, Drouin A. Tpit-independent function of NeuroD1(BETA2) in pituitary corticotroph differentiation. Mol Endocrinol. 2004; 18:995-1003. https://doi.org/10.1210/me.2003-0127.

28. Fratticci A, Grieco FA, Spilioti C, Giangaspero F, Ventura L, Esposito V, Piccirilli M, Santoro A, Gulino A, Cantore G, Alesse E, Jaffrain-Rea ML. Differential expression of neurogenins and NeuroD1 in human pituitary tumours. J Endocrinol. 2007; 194:475-484. https://doi.org/10.1677/JOE-07-0020.

29. Bell GI, Polonsky KS. Diabetes mellitus and genetically programmed defects in beta-cell function. Nature. 2001; 414:788-791. https://doi.org/10.1038/414788a.

30. Cerf ME. Transcription factors regulating beta-cell function. Eur J Endocrinol. 2006; 155:671-679. https://doi.org/10.1530/eje.1.02277.

31. Lee JE, Hollenberg SM, Snider L, Turner DL, Lipnick N, Weintraub H. Conversion of Xenopus ectoderm into neurons by NeuroD, a basic helixloop-helix protein. Science. 1995; 268:836-844. https://doi.org/10.1126/science.7754368.

32. Malecki MT, Jhala US, Antonellis A, Fields L, Doria A, Orban T, Saad M, Warram JH, Montminy M, Krolewski AS. Mutations in NEUROD1 are associated with the development of type 2 diabetes mellitus. Nat Genet. 1999; 23:323-328. https://doi.org/10.1038/15500.

33. Sharma A, Moore M, Marcora E, Lee JE, Qiu Y, Samaras $\mathrm{S}$, Stein R. The NeuroD1/BETA2 sequences essential for insulin gene transcription colocalize with those necessary for neurogenesis and p300/CREB binding protein binding. Mol Cell Biol. 1999; 19:704-713. https://doi.org/10.1128/mcb.19.1.704.

34. Moates JM, Nanda S, Cissell MA, Tsai MJ, Stein R. BETA2 activates transcription from the upstream glucokinase gene promoter in islet beta-cells and gut endocrine cells. Diabetes. 2003; 52:403-408. https://doi.org/10.2337/diabetes.52.2.403.

35. Mutoh H, Naya FJ, Tsai MJ, Leiter AB. The basic helixloop-helix protein BETA2 interacts with $\mathrm{p} 300$ to coordinate differentiation of secretin-expressing enteroendocrine cells. Genes Dev. 1998; 12:820-830.

36. Konishi Y, Ohkawa N, Makino Y, Ohkubo H, Kageyama R, Furuichi T, Mikoshiba K, Tamura T. 
Transcriptional regulation of mouse type 1 inositol 1,4,5-trisphosphate receptor gene by NeuroDrelated factor. J Neurochem. 1999; 72:1717-1724. https://doi.org/10.1046/j.1471-4159.1999.721717.x.

37. Liu M, Pereira FA, Price SD, Chu MJ, Shope C, Himes D, Eatock RA, Brownell WE, Lysakowski A, Tsai MJ. Essential role of BETA2/NeuroD1 in development of the vestibular and auditory systems. Genes Dev. 2000; 14:2839-2854. https://doi.org/10.1101/gad.840500.

38. Tani Y, Sugiyama T, Izumiyama H, Yoshimoto T, Yamada $\mathrm{S}$, Hirata Y. Differential gene expression profiles of POMCrelated enzymes, transcription factors and receptors between non-pituitary and pituitary ACTH-secreting tumors. Endocr J. 2011; 58:297-303. https://doi.org/10.1507/endocrj.k10e-389.

39. de Aguiar PH, Aires R, Laws ER, Isolan GR, Logullo A, Patil C, Katznelson L. Labeling index in pituitary adenomas evaluated by means of MIB-1: is there a prognostic role? A critical review. Neurol Res. 2010; 32:1060-1071. https://doi.org/10.1179/016164110X12670144737855.

40. Salehi F, Agur A, Scheithauer BW, Kovacs K, Lloyd RV, Cusimano M. Ki-67 in pituitary neoplasms: a review--part I. Neurosurgery. 2009; 65:429-37. https://doi.org/10.1227/01.NEU.0000349930.66434.82.

41. Zakir JC, Casulari LA, Rosa JW, Rosa JW, de Mello PA, de Magalhães AV, Naves LA. Prognostic value of invasion, markers of proliferation, and classification of giant pituitary tumors, in a georeferred cohort in Brazil of 50 patients, with a long-term postoperative follow-Up. Int J Endocrinol. 2016; 2016:7964523. https://doi.org/10.1155/2016/7964523. 